\title{
Shades of Grey
}

\author{
Bridget Russo
}

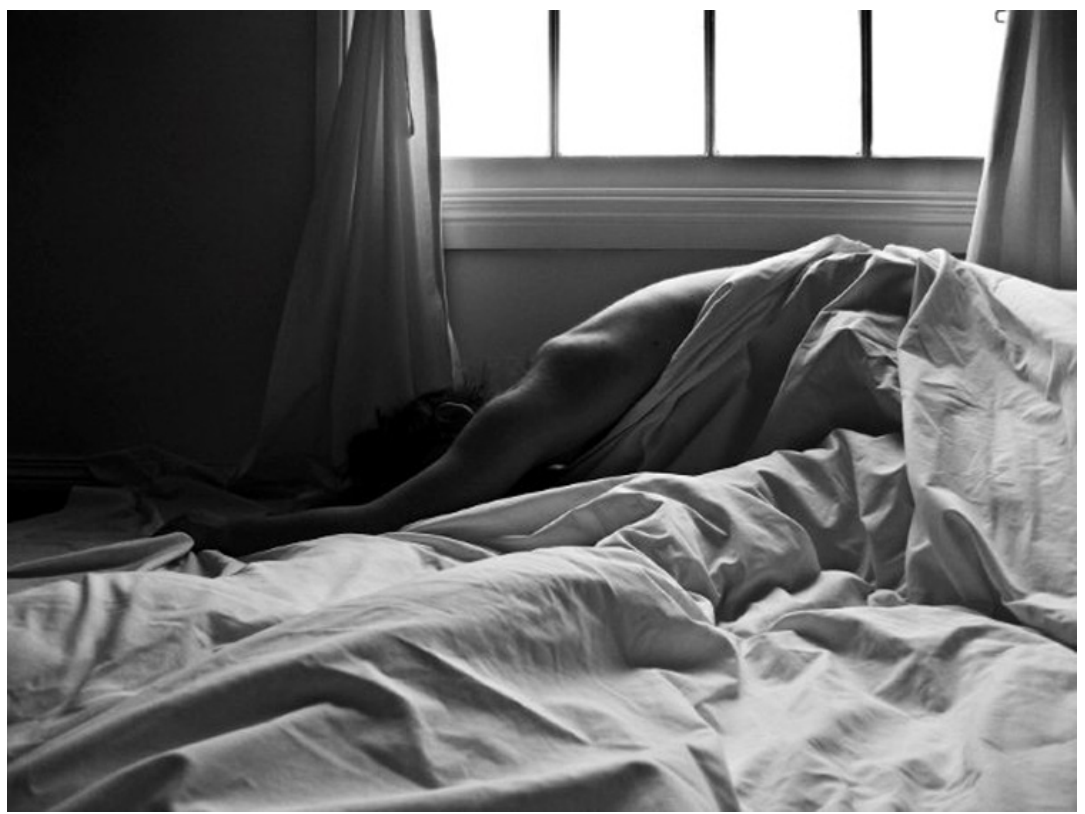

Offset no. 11 | 91 